\title{
UMA PROPOSTA SOBRE \\ A TRANSGERACIONALIDADE: O ABSOLUTO
}

Maria Emília Sousa Almeida

Professora do Centro

de Investigação

em Psicanálise e

Psicossomática de São José dos Campos/SP; doutora em Psicologia Clínica /PUC.
RESUMO: Apresentam-se algumas ideias sobre a transgeracionalidade. O absoluto designa certas representações sobreinvestidas por afetos que tendem a deter a cadeia associativa, levando às dificuldades na mudança psíquica. Ele revela traumas repassados dos pais para o filho, oriundos de uma linhagem arcaica. A análise de um casal fornece material clínico para as reflexões aqui contidas. Em suas origens clínicas e em seus desdobramentos teórico-clínicos, esse construto hipotético, oriundo de uma experiência clínica, articula-se a vários conceitos psicanalíticos. Esse operador tem sido útil à autora para entender o intenso sofrimento de alguns pacientes severamente traumatizados na trama das gerações da família.

Palavras-chave: Representação, ódio, sobreinvestimento, absoluto, transgeracionalidade.

ABSTRACT: A proposal on transgenerationality: the absolute. This article develops some ideas about transgenerationality. The absolute designates certain representations over-invested by affections which tend to deter the associative chain, leading to difficulties in the psychic change. It reveals past traumas transmitted from parents to their children, coming from an archaic lineage. The analysis of a couple provides the clinic material for some considerations about it. In its clinical origins and its theoretical and clinical development, this hypothetical construct, originated in a clinical experience, is related to several psychoanalytical concepts. It has been useful to understand the hard suffering of some of the author's patients severely traumatized in their families.

Keywords: Representation, hate, over-investment, absolute, transgenerationality. 


\section{UM CASO CLÍNICO}

Um executivo importante, racional e ponderado sempre trabalhou e viajou muito, bem como lutou para manter a família unida. Em função de melhores oportunidades profissionais, a família mudou-se para outras cidades. Quieto, ele defende que a infância de sua esposa foi muito difícil e compreende seus destemperos. Ela é emocional, impulsiva, agressiva, poetisa e clama pelo amor dele. Unidos há 24 anos, eles têm várias afinidades e buscam reorganizar a família.

O primeiro marido dela via-se como intelectual e artista e somente ela trabalhava. Ele a traía com mulheres mais jovens. Rejeitava-a e a criticava muito, face à decadência, às falas aos gritos e divergentes da família dela. Ele criou várias mentiras sobre a importância e o dinheiro de sua família. Na separação, ela lutou muito para ficar com os filhos do casal.

Ela trouxe três meninos para o segundo casamento. O marido cuidou dos filhos dela como seus, ensinou-lhes noções de ética e responsabilidade, e é respeitado e amado por eles. O novo casal teve, posteriormente, duas meninas, grande fonte de desavença e preocupação para ambos. Ele diz ter sido muito permissivo com as três grandes mulheres de sua vida. Proporciona gostos particulares à esposa: um equipamento caro para piscina, cirurgias plásticas, tratamentos de beleza e de saúde, e ainda a posse de uma égua. Por longo tempo, ele não impôs limites à extrema emotividade e à agressividade que percebia na esposa. Para fazê-la feliz, permitiu-lhe gastar à larga nas reformas de uma casa. Ainda assim, quase se envolveu com outra mulher. A esposa, extremamente estressada com a obra, sentia-se sozinha, abandonada e desamparada por ele, a trabalho em outro país. Responsável pelos pedreiros e pelas filhas, lesionou o joelho e ficou dois anos de cama. Porém, a casa significou um casulo de proteção e a materialização de seu propalado talento para gerar e construir.

Um paradoxo liga mãe e filhas, articulando-se à autodenominação da primeira como the keeper. Mantenedora da ordem, do bem-estar e da moralidade familiar, buscou ser perfeita e ter uma família também assim. Todavia, suas filhas extrapolaram limites e mentiam com relação a drogas e sexo. A necessidade de ser a guardiã advém de um legado matriarcal de tripla face. A avó de seu primeiro marido legou a ela um piano raro, e encarregou-a de cuidar dele. A bisavó e a avó do marido atual cuidaram sozinhas dos filhos. Ao zelar pelas filhas como guardiã, a paciente se contraespelha em sua mãe.

O império da violência materna infiltrou-se em sua psique. Sua mãe lhe dizia que não gostava dela, mandava-a embora e colocava-a de castigo num porão, com ratazanas. Quando castigada, deveria calar-se, ou apanharia mais. Aos 4 anos, sua mãe quase morreu, e a menina foi levada para despedir-se dela. Quando foi vê-la, foi rejeitada. Além disso, presenciou traições e brigas de seus pais, quando sua mãe quebrava as coisas da casa. Sentia-se abandonada e discri- 
minada, pois a irmã mais velha era "a bonita”, e a mais nova, "a inteligente". Ao separar-se do primeiro marido, sua mãe não a abrigou, ao contrário do que fez com suas irmãs.

Enquanto no âmbito doméstico o drama impunha seu crivo, no público havia sofisticação e charme. Sua mãe queria que as filhas fossem muito bem arrumadas aos eventos sociais. Certa grandeza e fartura estiveram presentes em sua vida. As frutas eram abundantes, mandadas por parentes ricos; ganharam um carro de um tio; além disso, a jovem ganhava roupas caras de uma senhora e apareceu numa importante coluna social. A violência abrange ainda o ramo paterno da família da paciente, mas a suaviza. Amada e eleita como especial pelo avô paterno, foi a única a ganhar joias bastante caras. Ele a defendia dos maus-tratos maternos e recitava poesias para ela, de joelhos. Contudo, quando ela e as irmãs corriam na frente, ele gritava em altos brados: "Piano!”, ou “Devagar”. Elas se envergonhavam dele. Ele disse-lhe: "Desconfie de tudo e de todos, até de seu pai."

Ambas as linhagens genealógicas de sua família contribuíram para que dores psicológicas e físicas a impregnassem. Essa violência perpassou a relação com o marido por meio da obrigação de acompanhá-lo nas viagens, da descoberta de camisinhas numa mala e dos abismos entre as vivências de cada um. Segundo ele, a traição não foi concretizada. Ela não encontrou outros indícios de traição, mas essa possibilidade reabriu, com violência, suas feridas. Suas viagens para outro país foram vistas como violentas e odiadas por ela. Sentia-se destruída.

A configuração psíquica do marido responde por sua adesão à de sua esposa. Na cepa materna da família, sua bisavó e avó ficaram viúvas muito cedo e arcaram sozinhas com os filhos. Dessa corrente, ele herdou a demanda de ser forte diante das adversidades, abolindo as emoções que enfraquecem. No ramo paterno da família, seu avô lutou na guerra e deixava a esposa grávida e sozinha, depois de cada retorno de férias. Somente quando este contava 6 anos, o pai do paciente assumiu o seu lugar de pai: cuidar da mãe e arrumar comida para os quatro irmãos. Dessa estirpe, ele se identificou com a demanda de ser resistente frente às catástrofes. Esse duplo caudal trans-histórico fomentou sua perseverança, sua capacidade de enfrentamento, seu sucesso e forjou sua elasticidade frente ao sofrimento com relação à esposa. Como o paciente, seu pai viajava muito e a família mudava-se de uma cidade para outra, em função do trabalho. Filho mais velho, o paciente era o representante da posição, segundo seu pai, que também o coloca no lugar de protetor da família.

A descendência do casal também está envolta em violência. Em antagonismo à sua progenitora, a paciente muito deseja ser uma boa mãe: amiga, companheira, brincalhona, capaz de passar conhecimentos e valores importantes para a vida. Entretanto, ao que parece, as filhas odeiam-na e rejeitam-na: a veem como descontrolada, exagerada e dizem que ela as envergonha em público. 
Para a paciente, sua dor vai durar para sempre. Culpa-se e sente-se fracassada pelas transgressões das filhas quanto às drogas e ao sexo. Sua intensa vigilância levou-a a descobrir suas mentiras. Além disso, em geral, não impôs limites à agressividade das filhas. Como exemplo, a paciente relata que, em certa ocasião, acordou com uma filha chutando-a, mas nada fez.

Outro viés dessa relação se destaca ainda: a paciente diz que defende suas filhas porque sua mãe nunca a defendeu. Tal defesa parece se dar de forma enfática e agressiva, como bem é retratado pelo relato de uma ocasião em que um vizinho deu uma festa até de manhã, e ela tocou guitarra e violino quando ele finalmente foi dormir.

Com a análise, desvelam-se o amor, a admiração e o respeito entre o casal. Ele reitera seu orgulho e sua vitória pela longa duração do casamento e pela saga da esposa como mãe. Em contrapartida, nela se deflagra outra fase traumática, ao se haver com a possibilidade de o marido viajar a trabalho e a necessidade de nova reforma da casa.

Rachaduras e novas dívidas reabrem sua vivência de traição, com uma violência incontida. Ela se debate numa tortura mental incessante e sem saída e enreda-o em exigências infindáveis. Impõe-se nela um paradoxo dirigido a ele: se ele fica no país, em nome da família e conforme demandado por ela, o faz por obrigação; além disso, ele poderia ir embora de repente e, se assim fosse, ela aceitaria viajar com ele; se ele vai para o exterior, ela se sentiria abandonada, violentada e impotente. Sente-se traída, não confia nele e não acredita em seu amor. Apesar de ele reiterar seu desejo de manter o casamento, ela deseja afastar-se dele e da família, nesse período caótico. Entrevendo sua dificuldade de amar, ela vai para uma análise individual.

\section{ALGUMAS CONSIDERAÇÕES TEÓRICAS ACERCA DO ABSOLUTO}

Este artigo visa fornecer uma perspectiva teórica sobre o trauma transgeracional. O caso clínico apresentado permite o desenvolvimento de algumas formulações.

A ideia de absoluto deriva de enigmas e impasses observados em minha clínica. Caracterizo-o como constituído por representações sobreinvestidas de ódio e horror, tais como as que se seguem: ser abandonado, desamparado, rejeitado, fracassado, derrotado, devedor, não-amado, para sempre sem lugar no mundo, sofredor ao infinito, amaldiçoado ad aeternum. É ainda ser o zero, ser o nada, ser a nulidade, ser impossível realizar seu desejo e estar absolutamente proibido de realizá-lo. Por outro lado, em uma defesa onipotente contra o ódio, compreende igualmente: ser fenomenal, ser o colosso, ser 0 melhor da história, ser 0 melhor do mundo numa função e estar a anos-luz de alguém. O absoluto engloba, pois, desde representações onipotentes de absoluta grandeza do sujeito até as de insignificância absoluta (ALMEIDA, 2003). 
Para a elaboração deste constructo foi necessário articulá-lo a quatro correntes da psicanálise. A princípio, o absoluto filiar-se-ia à teoria das representações de Freud (1915a/1976). Porém, embora Freud destaque os investimentos libidinais nos representantes ideativos, não o faz considerando os de ódio. Por outro lado, ainda que enfoque o ódio, Klein (1932) fala em ataques destrutivos aos objetos internos - e não em investimentos de ódio nas representações. Índice de traumas para além da relação primária, o absoluto liga-se à transgeracionalidade de Eiguer (1997) e de Kaës (1998). Os dois autores investigam em suas obras a transmissão da vida psíquica entre as gerações, os efeitos do trauma sobre a representabilidade psíquica, os segredos, as criptas, as pragas, a vergonha, entre outros. Termo cunhado por Herrmann (1991), o sistema das representações, quando é atingido em sua representabilidade pelo trauma ancestral, adquire outra concepção no contexto do absoluto. Cada um desses vértices fornece elementos teóricos que ajudam a autora a construir a formulação do absoluto, sem que essa hipótese se associe, em particular, a nenhum deles. Dessa maneira, dialoga-se com eles, sem desrespeitar suas diferentes bases metapsicológicas.

De modo específico, o absoluto articula-se à economia psíquica e às dificuldades no trânsito entre representações. Com apoio do enfoque econômico de Freud (1915b/1976), é possível considerá-lo a partir das vicissitudes das quantidades de excitação, visto que no inconsciente haveria conteúdos catexizados com maior ou menor força. Com apoio de Herrmann (1991), é possível apontar que, nesses casos, o paciente sofre de imobilidade psíquica. Assim, condições peculiares de seu desenvolvimento paralisaram sua história em torno de um sentido, que se congelou. Para este autor, os fatos e as relações emocionais que dão forma restritiva ao desejo são o que constitui os traumas. Vale dizer, entretanto, que o trauma, mais do que um evento terrível, constitui-se, no mais das vezes, por uma repetidíssima forma de relação emocional, que age através de pequenos choques, e não de golpes mortais.

Circunscrevendo o conceito, portanto, o que chamo aqui de absoluto é o sobreinvestimento de afetos disruptivos — ódio e horror — em certas ideias, o que, por sua vez, impede o investimento de um afeto impulsionador do desejo — ou do amor - em outras. Essa intensa concentração energético-afetiva nas representações do absoluto configuraria sua vicissitude econômica e traz a marca de uma dificuldade de trânsito ou de mobilidade das demais representações.

Se uma análise propõe-se a trazer à consciência representações antes expulsas dela, permitindo que a mudança psíquica tenha lugar, devido ao trânsito entre as autorrepresentações (HERRMANN, 1991), o absoluto seria responsável pela impossibilidade dessa mudança psíquica em pacientes gravemente traumatizados por seus pais. Estes teriam transmitido certa forma violenta de relação emocional bastante repetitiva, igualmente herdada por eles. Deste modo, esse 
trauma ancestral permitiria deslizar o cortejo destrutivo de representações e afetos numa família, comprometendo, assim, o funcionamento de seu sistema das representações.

O sistema representacional tem a função de representar os diferentes impulsos, relações de objeto e estados mentais do sujeito. Já o absoluto remete aos traumas em que a herança de representações aprisiona o sujeito à parentalidade e à ancestralidade. Veiculados pelos objetos primários a partir das relações ancestrais, os traumas no desejo do sujeito atingem a atividade representativa desse sistema. Assim sendo, bloqueiam a força de realização do desejo do adulto (ALMEIDA, 2003). Deste modo, a efração dos traumas teria um impacto desorganizador nesse sistema, devido aos afetos que investem algumas representações. No trauma ancestral em pauta, as representações do absoluto são sobrecatexizadas por duas formas afetivas que detêm a propriedade de fixar as representações que investem. Ódio e horror respondem por sua fixação no estrato consciente do sistema representacional. Em seus estratos inconscientes, ficam representações favoráveis ao exercício pleno do desejo: ser competente, inteligente, digno, com méritos próprios, bem-sucedido, por exemplo.

A violência do trauma é muito discutida em Psicanálise, seja transgeracional ou não. Kaës (2001), por exemplo, propõe que há uma relação entre a necessidade de transmitir experiências traumáticas e a violência da herança. Para Botella e Botella (2002), no trauma, a violência dos afetos desorganiza o psiquismo. Levy (2003) afirma que em situações traumáticas ocorrem vivências que, por sua violência, sua intrusividade e pelo desamparo que geram, tornam-se intraduzíveis e produzem várias perturbações no sujeito.

Nessa clave, a violência do legado transgeracional vem numa esteira de acontecimentos, ações e reações, que atingem uma família em sua sucessão de gerações. Perpassa os vários estratos geracionais da família: ascendentes secundários/avós; ascendentes primários/pais; descendentes primários e seus objetos de amor/maridos ou esposas e seus descendentes secundários/filhos e filhas. O repasse de uma herança psíquica violenta ultrapassa o indivíduo e o influencia em inúmeros setores de sua vida adulta.

No que diz respeito à conformação de uma família, uma transmissão psíquica cruzada das genealogias paterna e materna institui os fundamentos que regem o funcionamento de seus membros. Nessa transmissão, cruzam-se a identificação e a contraidentificação, a confluência traumática entre as linhagens paterna e materna, a delegação de posições, o entrelaçamento entre representações e afetos e os gradientes diferenciais de amor e de ódio. Estes são os afetos fundantes, investidos nas representações, que transitam numa família. Cada um desses elementos será analisado a seguir, de modo a permitir que se discuta a transmissão psíquica. 


\section{A TRANSMISSÃO PSÍQUICA}

A identificação é um importante elemento para pensar o psiquismo em Psicanálise. Freud (1921) diz que a identificação molda o ego da pessoa, segundo certos aspectos de um modelo. Constitui a forma original de laço emocional com o objeto e se torna sucedâneo para um vínculo de objeto libidinal, por meio da introjeção do objeto no ego. Lacan (1949) diz que o estádio do espelho é como uma identificação: transformação produzida no sujeito ao assumir certa imagem especular. Esta manifesta a matriz simbólica na qual o eu se precipita em uma forma primordial, antes de sua identificação com o outro.

Ainda no tocante à identificação, na transmissão da vida psíquica entre as gerações, Eiguer (1997) diz que nos avatares da tragédia de indivíduos tomados por lutos muito difíceis, eles vivem como seus os acidentes traumáticos que atingiram seus pais ou avós. Isso se deveria a uma identificação atributiva, na qual o pai atribui ao filho uma vivência interior, um traço de sua pessoa, certa representação de seus objetos internos. Essa identificação, tão estruturante quanto desorganizante do eu, atua nos processos alienantes do transgeracional.

Junto com a identificação, a contraidentificação do sujeito — com seus pais e ancestrais - aparece na clínica do absoluto. Propõe-se que a contraidentificação constitua um processo de formação do eu e um mecanismo de defesa do sujeito em seu desenvolvimento: facetas de um mesmo movimento psíquico do eu. Nesse caso, o sujeito se contraidentifica com características odiadas de seus pais em sua infância, às quais atribui seu sofrimento. Contudo, elas favorecem a realização de seu desejo em sua vida adulta. A partir de sua história, o sujeito pode se contraidentificar com a determinação, o empreendedorismo e o sucesso de seu sádico e odiado pai, traços aos quais atribui seu abandono, seu desamparo e sua humilhação. Ao sobreinvestir de ódio as representações de ser abandonado e ser desamparado, deixa de investir de amor as de ser empreendedor, ser determinado e ser bem-sucedido como o pai. Estes tipos de representação e de afeto favorecem a atualização de seu desejo no presente, atingido pelo trauma no passado.

Numa família, o amor e o ódio adquirem maior ou menor magnitude e associam-se às correntes identificatórias e contraidentificatórias paternas e maternas. Na contraidentificação, o filho erige grande parte de sua identidade em franca oposição à de seus pais e mobiliza forte ódio a eles. Seus efeitos psíquicos tendem a ser paradoxais, pois alguém prevalentemente contraidentificado com seus pais produz, na relação com os próprios filhos, o mesmo efeito do qual buscou escapar através desse mecanismo. Quando o ódio e a contraidentificação prevalecem sobre o amor e a identificação estruturante, a flexibilidade dos membros da família tende a ficar restrita ao lidar com suas heranças. Porém, uma figura contralateral à tessitura familiar pode atenuar seus efeitos, ao investir em um dado sujeito certo quantum de amor. Diferenciados da urdidura familiar 
aprisionante, um professor, um religioso ou uma madrinha podem se encantar com uma criança - com a qual se identificam a partir de uma característica em comum - e investi-la de amor. A partir dessa rede de determinantes da família que modela os psiquismos individuais, dá-se a somatória, a diminuição ou a multiplicação de seus efeitos sobre um sujeito. A somatória aparece quando a vivência de ódio da criança é forjada pela dupla carga de ódio — investida nela - por ambos os pais. A atenuação de seus resultados deletérios ocorre quando um dos pais ou uma figura externa ao conflito transgeracional investe-a de amor. Na multiplicação, o sofrimento do sujeito com o ódio dos dois genitores é exacerbado por seu sofrimento com outras figuras familiares e ainda acrescido daquele vivido com um objeto idealizado. Este é parte de suas defesas contra os pais perseguidores, mas escamoteia sua própria carga persecutória. Um par muito idealizado que também faz o herdeiro do trauma arcaico sofrer — contrariando suas expectativas e atingindo-o nos mesmos pontos traumáticos - multiplica sua dor ao infinito.

Na herança transgeracional, vários planos de intersecção favorecem as reações dos membros de uma família, sob o impacto desses complexos caudais que se cruzam entre si.

No que diz respeito à paciente do caso ora apresentado, esta se identifica com o avô paterno e introjeta a agressividade e a desconfiança como elementos essenciais de sua psique. Suas reações expansivo-agressivas também são frutos da identificação com outros membros da família: mãe, irmãs e tias. Abandonada, desamparada e rejeitada pela mãe, contraidentifica-se com ela, em grande medida. Mas, ao mesmo tempo, também há uma identificação. Assim, por contraidentificação, tenta superproteger as filhas, mas o faz com a veemência agressiva de sua mãe, por identificação. Em suas filhas, o descontrole, a agressividade e a vigilância maternas geram ódio e rejeição. Elas se contraidentificam com sua mãe, tal como a paciente e suas irmãs com relação a sua genitora. A contraidentificação agressiva da paciente com sua mãe nutre-se de aspectos agressivos de sua identificação com o avô. Ela se contraidentifica também com a postura calma do marido, passiva e omissa, na visão dela. Ele não tomaria atitudes imprescindíveis, num momento preciso e definido por ela. Por outro lado, suas reações intempestivas em público oscilam entre a diversão e a agressividade, entre o lúdico e o drama. A herança traumática oriunda do avô paterno foi suavizada por seu lado artístico e poético, e apresenta-se na atração sentida pelo marido-artista e no uso de instrumentos musicais ao sentir muita raiva.

A vergonha pública é marcante na família. Ela se envergonhava dos escândalos sexuais e agressivos dos pais. Tal como ela e suas irmãs se envergonhavam do avô paterno. Da mesma maneira, suas filhas envergonham-se dela. Ela, por sua vez, se envergonha dos escândalos sexuais das filhas. Essa sequência exem- 
plifica os fatores que agravam ou abrandam a herança psíquica impregnada em seus ascendentes e descendentes. Assim, uma sorte de multiplicação dos efeitos da identificação e da contraidentificação e a prevalência do ódio sobre o amor repassam adiante um sofrimento arcaico em sua família.

Para Kaës (1998), os membros do grupo transmitem configurações de objetos psíquicos (representações, afetos e fantasias) munidos de seus vínculos, incluindo relações de objeto. Certos membros do grupo que precede o sujeito mantêm-no numa matriz de investimentos, predispõem sinais de reconhecimento, designam lugares, apresentam objetos de satisfação, oferecem meios de proteção e ataque, traçam vias de realização e enunciam limites e interditos. Sustentam o recalcamento de representações, a supressão de afetos e a renúncia pulsional no herdeiro. Assim, o sujeito é nomeado, representado e situado segundo o desejo dos porta-vozes dos desejos, interditos e ideais do grupo.

Inúmeros feixes constitucionais, relacionais e circunstanciais contribuem para a gênese de um traço de personalidade e para certa emoção de uma família. Em cada componente, esse entrecruzamento dos elementos tende a exacerbar ou atenuar uma predisposição de reação e a constituir um traço de sua personalidade, em resposta a certas formas de relação e emoções em vigência na família. Para determinada emoção caótica, concorre um evento traumático não representado adequadamente e transmitido para as demais gerações. Esse complexo cruzamento de conteúdos psíquicos igualmente influi na atração e na escolha de um par amoroso, por parte do adulto.

Nessa esteira, três mananciais da formação psíquica dos sujeitos atraem elementos de dois grupos familiares e respondem pelos mais intrincados processos transgeracionais. Assim, a conjunção dos legados paterno e materno no sujeito potencializa certas representações, que o ligam ao seu par. No caso apresentado, do paciente ser forte face às adversidades e ser resistente frente às catástrofes, trata-se de representações que se autorreferendam, oriundas das duas cepas psíquicas de sua família. Suas duas autorrepresentações centrais ligam-se por complementaridade às três autorrepresentações axiais à paciente ser abandonada, ser desamparada e ser rejeitada, que denotam as adversidades e catástrofes vividas com sua mãe. Os destemperos da esposa constituem as adversidades a serem vencidas e suas catástrofes relacionais devem ser enfrentadas por ele.

Eiguer (1998) diz que as representações entre gerações organizam a escolha de objeto dos parceiros: o tipo de família que desejam fundar e a educação mais conforme com o ideal familiar. A complementaridade entre as representações ancestrais nos cônjuges não é excepcional e responde a uma lógica particular. $\mathrm{Na}$ herança, a vergonha surge quando se trata de um fantasma. Este designa o enquistamento no inconsciente do sujeito de parte das formações inconscientes do outro, que o persegue: mandato ancestral sobre a descendência. 
Outro fator de enlace do par é a posição em que o filho é colocado pelos pais, que o faz atender à demanda do outro. No ramo paterno do paciente, o filho mais velho é posicionado como pai há três gerações. Nos feixes paterno e materno, as mães lutam sozinhas pelos filhos. A paciente lutava sozinha pelos filhos, quando a ele urgiu ser o pai forte e resistente. Ademais, certos traços reprimidos em suas famílias de origem atraem dois membros de famílias diferentes, mas complementares patologicamente. Na paciente, o traço expansivo-agressivo alimenta-se da torrente de duas linhagens. No paciente, o traço retraído-passivo, a racionalidade e a autocrítica quanto à sua agressividade têm raízes europeias e brasileiras. Vergonha, culpa e explosividade são parte da carga pré-histórica anterior à história da paciente. Força, resistência, determinação, racionalidade, contenção de emoções — ódio — e valorização de outras — orgulho — são centrais na procissão dos antepassados do analisando.

A singularidade da formação psíquica do sujeito tende a gerar certas representações e afetos nos estratos conscientes e inconscientes de seu sistema representacional. Na paciente, o acúmulo da agressividade — em duas vertentes de sua árvore genealógica - reverte para um sobreinvestimento de ódio em três representações. Ser abandonada e ser desamparada são nomeadas conscientemente por ela, enquanto ser rejeitada aparece sob a denominação de ser discriminada. Todavia, seu ódio e horror a sua mãe são afetos inconscientes. Juntam-se ao ódio de sua mãe por ela e ao seu amor e ódio pelo avô paterno.

Este lhe repassou uma lei absoluta, que a indispõe inclusive contra seu pai. Verdade incontestável, da qual tão-somente o senhor da lei escapa, prende-a a um passado torturante e persistente no tempo. Deve desconfiar e vigiar o outro até encontrar a falta, o erro, a traição, a vergonha e a culpa. Tal mandato ancestral gera sequelas deletérias na paciente. Sua desconfiança do marido atormenta-a, e ela o atormenta. Sua mãe foi abandonada, rejeitada e apanhou muito do pai. Repetiu essa trama com a filha-paciente. Ela repete grande parte disso com suas filhas. Nesse cativeiro que perdura há muito, os atos extremados repassam abandono e crueldade dos pais quanto aos filhos, que os rejeitam. Prevalecem o ódio, a violência e a desorganização nas duas estirpes de origem. Vigora a efração causada pelo trauma, que atinge o sistema representacional da família.

\section{SOBRE A IDENTIDADE: POSSIBILIDADE, PROBABILIDADE E REALIDADE}

Para a reflexão seguinte contribuem dois extratos da obra de Herrmann (1998). A realidade, tanto quanto a identidade, são representações, e são indissociáveis uma da outra. A noção discriminada da hierarquia dos possíveis determina vários graus de probabilidade para as representações do sujeito, diferenciando as quase certas das muito remotas. Na patologia dos possíveis se tornam indiferenciadas condições possíveis e fatos reais. 
Essas ideias permitiram à autora pensar as diferenças entre possibilidade, probabilidade e realidade. Sinalizam a capacidade de discriminação do sujeito ao avaliar os aspectos lógicos ou ilógicos de suas vivências. A engrenagem do trauma ancestral fragiliza essa capacidade diferencial do sistema quanto ao juízo de realidade, essencial ao sujeito.

A atividade representativa do sistema confere uma boa organização mental ao sujeito. Contribuem para ela: a lógica e a clareza do pensamento, a diferenciação de suas classes, as noções de tempo e espaço, a discriminação sujeito-objeto, a integração amor e ódio, a distinção entre os sentidos inconscientes das vivências do passado e do presente. Em contrapartida, as distorções lógicas do pensamento, os desvarios do tempo, as distopias do espaço, os paradoxos e as posições psicológicas são filigranas do trauma ancestral. São desarranjos operacionais que assolam o sistema representacional do 'vassalo' do absoluto.

O pensamento organizado sustenta-se numa relação entre passado, presente e futuro. Enquanto o presente é volatilidade fugidia, o passado é granular e dirige-se de pontos mais distantes para outros cada vez mais próximos ao presente. O pensamento organizado, consciente e lógico diferencia inclusive suas categorias: possibilidade, probabilidade e realidade; ilusão e verdade; dúvida e certeza. Para tanto, faz mediações para ajuizar o maior ou o menor grau com que uma possibilidade se aproxima da realidade. A despeito de sua qualidade de representações subjetivas e passíveis de racionalização, a realidade designa maior capacidade lógica do que a possibilidade quando o sujeito precisa sopesar certas nuances e certos indícios que tornem consistente sua estimativa dos fatos, que geram nele determinadas emoções. Cabe-lhe distinguir se um evento é possível, provável ou real; com maiores chances de ser ilusório ou verdadeiro; dubitativo ou inquestionável. Todavia, quanto maior a energia disruptiva dos afetos que atingem o sistema, essas propriedades do pensamento são destituídas de sua eficácia e funcionalidade. Sobra-lhe muito sofrimento.

Essas alterações aparecem na paciente mediante duas configurações traumáticas de ideias e afetos de sua infância, perpetradas até hoje. A primeira é composta por desconfiança-vigilância-traição, e a segunda, por abandono-desamparorejeição. Seus núcleos ideativos são traição, abandono e rejeição, que se interligam ao trinômio possibilidade-probabilidade-realidade. Da ordem da realidade vivida com sua mãe, o abandono e a rejeição adquirem o sentido de para sempre em sua relação com as filhas. Torna-se um irreal indubitável. Uma possibilidade — traição — é vivida como realidade, com o atual marido, dada a realidade da traição do anterior. Como a consistência de seus sinais não é examinada racionalmente, a possibilidade é alçada à condição de probabilidade. A probabilidade, tampouco, é analisada, ocorrendo um salto ilógico da possibilidade ao plano da realidade e da certeza absolutas. A possibilidade — vivida como realidade violenta — é 
investida de ódio e posicionada antes de suas experiências atuais, colocando-as sob a égide de um sofrimento sem escapatória.

Essa fatoração concorre para forte enodamento confusional, pois a magnitude violenta desta possibilidade a eleva da condição de aspecto parcial para a de totalidade negativa. Assim, a possibilidade de prazer e de mudança de um estado mental para outro melhor não entram no fluxo associativo. Não compõem um todo integrado de vivências da paciente consigo e com seus objetos atuais, que atenuem os aspectos negativos com os anteriores. Em suma, o influxo da violência transgeracional transborda a capacidade de seu sistema representacional de representá-la.

Essa força disruptiva do transgeracional se aplica também ao estatuto do tempo. Os eixos horizontal, vertical e transversal do regime temporal permitem entender a abordagem do sofrimento pelo sistema das representações. O eixo horizontal designa o tempo presente; o vertical nomeia o passado individual, mais ou menos remoto; e o eixo transversal, o passado ancestral. Todos esses planos indiferenciam-se na dor ancestral. Na paciente, o transcorrer de uma vivência violenta — ser abandonada e ser rejeitada — num tempo ilimitado das gerações adquiriu o significado de para sempre e infinito. Fora de limites humanos e dentro de um tempo mítico, essa violência ultrapassa sua vida individual.

No tocante ao para sempre, Faimberg (1985) aponta um tipo de identificação que condensa uma história que, em parte, não pertence à geração do paciente. Sua introjeção da fórmula parental 'Amo, sou eu (o objeto bom sou eu) e odeio, és tu (o objeto mau és tu)' define a dramática situação em que ele fica alienado por suas identificações inconscientes com a totalidade da história dos pais. Essa identificação com a lógica narcisista de seus pais congela seu psiquismo em um 'para sempre' de sofrimento inconsciente.

Ademais, o raciocínio da paciente era crivado por progressões e retrocessos ilógicos do tempo. Idas e vindas ilógicas do pensar rompiam a sequência que vai do passado mais longínquo para o presente. O tempo linear consciente era avassalado por uma cronologia fantástica inconsciente. História e história ao reverso se sobrepunham de forma caótica. Causa de intensa dor no presente, a traição e as mentiras das filhas confundem-se com a possível traição e a mentira do atual marido. Contudo, ambas parecem ter como geratriz a traição real do primeiro marido — há mais de 24 anos, e por várias vezes - e suas mentiras. Essas, por sua vez, juntam-se à lei do avô paterno, de seu passado transgeracional. Para se defender dessa lei, ela muniu-se da crença onipotente de que não se enganaria e confiou cegamente no primeiro marido. Com as traições e mentiras, tal lei passou a vigorar com toda a força. De seu passado transgeracional, as traições de seus pais enredam-se nas de suas filhas. Por conseguinte, formou-se um curto-circuito autoalimentado e paralisante do sistema. 
A dimensão espacial do pensamento humano imbrica-se à dimensão do tempo. Um adendo espaçotemporal visa examinar as vivências dolorosas da paciente: mudanças de cidade e de condições anteriores. Profissional competente, muito considerada pela chefia e muito bem remunerada antes de casar, ela desistiu de tudo para cuidar da família. Ao se separar, dividiu o aluguel de um apartamento com o segundo marido, no Centro da cidade. Depois, se mudaram para um condomínio luxuoso cercado por arredores violentos. Nessa gaiola de ouro, ela mostrava passarinhos, animais e árvores para as crianças. Na escola, perguntavamlhe sobre esse lugar bonito tão comentado por elas. O marido faz intervenções que permitem entendê-la. Esclarece que se trata do condomínio, mas a analista entendeu que ela pudera focar o melhor da experiência e suavizar o pior. Saltos espaçotemporais em seu discurso insurgem-se contra a sequência lógica que guarda respeito a lugares e tempos. Confunde espaços como apartamento e casa; identidades como a dela e a do marido; condições materiais, como ser locatária do apartamento e ser proprietária da casa; condições psicológico-materiais, como ser profissional, com autonomia pessoal-financeira e ser mãe-esposa, dependente do dinheiro do marido. Condição psicológica, seu imenso desejo de ser uma grande mãe, que transforma dificuldades em poesia e encanto, talvez tenha favorecido a impressão da analista.

\section{SOBRE PARADOXOS E POSIÇÕES SIMBÓLICAS}

Fonte de inspiração para pensar certa face do absoluto, outro autor faz-se necessário. Racamier (1980) define o paradoxo como uma formação psíquica que liga indissociavelmente duas proposições inconciliáveis. Submete um indivíduo a duas injunções, sendo-lhe impossível obedecer a uma sem desobedecer à outra. Sua incompatibilidade não é percebida. É uma agressão ao eu, que suscita um ódio intenso. O ódio não é discernido, pois o paradoxo provoca uma confusão dos sentimentos. Em 1991, Racamier diz que na negação das origens está a chave das organizações paradoxais, que se alimentam de energias agressivas. Pais bastante fixados na negação de sua sexualidade e de suas raízes edipianas não podem legar aos filhos essa herança essencial. O paradoxo ata o pensamento do sujeito numa rede paralisante.

Um paradoxo fundante pode ser constitutivo do sistema representacional do sujeito. Na paciente, seu paradoxo axial parte do desejo de ser amada; mas, ao ser traída pela mãe, é violentada, passa a ser desconfiada ao extremo e a se defender ao máximo do amor. Surge uma sequência de representações: ser amada; ser traída; ser violentada; ser desconfiada; ser invulnerável ao amor. Seus incomensuráveis desejos de ser amada e ser invulnerável ao amor formam um apelo paradoxal impossível de ser atendido pelo marido. 
Matriz de seu paradoxo, a vivência do absoluto é contundente na paciente. Ser desamparada, fracassada e não amada por pais desamparadores, fracassados e incapazes de amar são representações sobreinvestidas de ódio. Representa-se ainda como: ser insaciável num registro de tempo infindável. Ser traída, ser frustrada, ser fracassada e ser solitária forma uma coligação que dificulta uma nova conexão ideativa: ser amada, ser confiante, ser bem-sucedida e ser parceira. Em seu marido, as ideias de ser protetor, ser forte, ser resistente, ser orgulhoso e ser vencedor tornam-no suscetível ao absoluto nela.

As posições simbólicas na família são constituídas por grupos de representações do sistema, de base histórico-geracional. Designam os lugares psicológicos de seus membros e a maneira pessoal deles perceberem e reagirem aos conflitos ancestrais. Nas posições mesclam-se representações de papéis - pai, mãe, filho - e outras representações pessoais: ser amado ou não-amado; vencedor ou derrotado; poderoso ou desfavorecido. Elas caracterizam-se por uma espécie de forma e conteúdo representacionais, investidos por afeto. Sua forma é garantida pelo lugar do sujeito, e seu conteúdo, pela função que lhe imputam na estrutura familiar. O locus de filho pode ter como conteúdo ser superprotegido, massacrado ou abandonado.

Uma posição muito frequente na família é a de guardiã, em geral ocupada pela figura materna ou por sua substituta. No cotidiano e na clínica psicanalítica, pode-se encontrar a guardiã 'saudável', mais rara, e a 'patológica', bastante comum. Esses dois tipos básicos de guardiãs desdobram-se numa multiplicidade de versões. Na guardiã 'saudável', o amor predomina sobre o ódio em suas relações com o outro. Suas regras para com seu protegido são claras e visam atingir objetivos benfazejos para ele. Uma ou mais figuras amorosas acolheram-na em momentos críticos com as figuras parentais. Assim, ajudaram-na a refazer esses vínculos. Suas dificuldades psicológicas não demandam, de modo imperioso, uma análise. Com limites, elas administram seus conflitos. Certa guardiã saudável antecipa os efeitos nocivos de uma situação, evita-os e convoca outras pessoas para ajudá-la. Acolhida, apoio ao outro e ações sociais compõem seu repertório. Sua doação, generosidade e empatia com o outro são correntes de amor e vida. Outra, preventivamente, coloca seus pais num plano de saúde. Dirige em viagens perigosas e evita riscos. Toma a si a direção dos negócios, sem visar quaisquer vantagens espúrias.

Já os tipos de guardiãs 'patológicas' mostram-se à exaustão na clínica e na vida. Certa guardiã dos desastres abdica de sua identidade de mulher. Contraidentificada com sua mãe, adota uma criança deficiente mental. Cuida de seu pai, com Alzheimer. Vive evitando que ele provoque desastres. Desastrada, machuca-se física e psicologicamente. Outra é a guardiã da união destrutiva. Ainda que lute muito pela união da família, vive a brigar com os filhos, ante a mínima diferença entre suas expectativas não explicitadas e as ações deles. Por 
identificação projetiva, cobra que eles realizem o que ela não realizou. A guardiã dos alimentos e do dinheiro carrega o trauma da fome e do desamparo. Essas guardiãs patológicas assenhoram-se de forte destrutividade arcaica.

No caso apresentado, os dois pacientes foram instituídos como guardiões em suas famílias de origem. Atualmente, ela é a guardiã patológica da moralidade das filhas. Sua desconfiança delas tem como reverso sua falta de confiança e competência nos vínculos amorosos. Cobra que o marido controle as filhas e as lembre do poder profissional dela, mas tem raiva e inveja do poder dele. Há várias gerações, a desconfiança e a vigilância transbordam na família. Guardião substituto do pai ausente em sua infância, o paciente adulto substitui os ausentes pai e marido da esposa. Representante da posição de pai, ele orgulha-se da luta dela como mãe e cuida de seus filhos. Logo, uma cadeia de ideias e afetos une os membros da família. Cerne do trauma ancestral, há uma indefectível ausência da diferença entre as gerações.

\section{CONSIDERAÇÕES FINAIS}

Diante de um trauma, frequentemente, o sujeito perde o contato com sua dor e opacifica seus sentidos, que permanecem inconscientes. A abrangência e a profundidade da dor, causada por ele, configura suas modalidades. Dentre as diferentes modalidades de acontecimentos de potencial traumático, o trauma ancestral é especialmente destrutivo, no que diz respeito ao alcance de seus danos à eficácia representativa do sistema das representações. O que ao longo do artigo descrevemos como o absoluto é um de seus modos de presentificação. Constelação psíquica do hospedeiro de um sofrimento trans-histórico, o absoluto revela-se mediante fortes gradientes de ódio nas representações de si e das figuras parentais. Os elementos que entram na composição do absoluto foram organizados ao longo do trabalho para análise e dizem respeito às representações de si, de tempo, de espaço, paradoxos, pensamentos e posições simbólicas.

No caso estudado, a concentração traumática na paciente deriva de sua captura híbrida pelos dois caudais da família. Fomenta a atração entre ela e seu par, ainda que a saturação traumática nesse último seja menor e enverede pelos meandros da resiliência. Nesta, a capacidade de enfrentamento dos problemas da vida adulta se nutre de amor, potência e criatividade. Cativa do absoluto, a mudança na opacificação dos vínculos amorosos impõe que a análise permita a concatenação entre seu trauma com novas ressignificações. Estas permitirão reorganizar a desertificação amorosa do eu. Para tanto, a depuração da contundência do trauma é necessária, pois permite sua inserção no circuito representacional mais amplo do sujeito. Com ela, as representações conformes ao exercício de seu desejo - ser amado, ser capaz de amar, ser competente, bem-sucedido, dedicado, com méritos próprios — poderão ser investidas de amor e integrar seu pa- 
trimônio representacional. Apenas então, a força de seu desejo — voltada para sua realização — poderá aparecer em toda a sua magnitude.

Recebido em 13/5/2008. Aprovado em 1/12/2008.

\section{REFERÊNCIASS}

ALMEIDA, M. E. S. (2003) A clínica do absoluto: representações sobreinvestidas que tendem a deter o encadeamento associativo. Tese (doutorado em Psicologia Clínica), PUC-SP.

BOTELlA, C. e BOTELLA, S. (2004) Irrepresentável: mais além da representação, Psychê. Revista de Psicanálise, 8/14, São Paulo, jul-dez, p. 193-196.

EIGUER, A. (1997) Transgénérationnel et temporalité. Revue Française de Psychanalyse, 61/5, Paris: PUF, p.1.855-1.862.

(1998) "A parte maldita da herança”, in EIGUER, A. (Org.) A transmissão do psiquismo entre gerações, São Paulo: Unimarco, p. 21-84.

FAIMBERG, H. (1985/2001) “A telescopagem das gerações: a propósito da genealogia de certas identificações”, in KAËS, R. (Org.) Transmissão da vida psíquica entre as gerações, São Paulo: Casa do Psicólogo. p.71-93.

FREUD, S. (1976) Edição standard brasileira das obras psicológicas completas de Sigmund Freud, Rio de Janeiro: Imago.

(1915a) “A repressão”, v. XIV, p.141-158.

(1915b) “O inconsciente”, v. XIV, p.165- 178.

(1921) "Psicologia de grupo e análise do ego”, v. XVIII, p.241-338.

HERRMANN, F. A. (1991) A clínica psicanalítica. São Paulo: Brasiliense. (1998) Psicanálise da crença. Porto Alegre: Artes Médicas.

KAËS, R. (1998) "Os dispositivos psicanalíticos e as incidências da geração”, in EIGUER, A (Org.) A transmissão do psiquismo entre gerações, São Paulo: Unimarco, p.5-19.

et al. (2001) A transmissão da vida psíquica entre gerações. São Paulo, Casa do Psicólogo.

KLEIN, M. (1932/1981) Psicanálise da criança. São Paulo: Mestre Jou.

LACAN, J. (1949/1987) "El estadio del espejo como formador de la función del Yo [Je] tal como se nos revela en la Experiencia Psicoanalitica”, in Escritos I, México, Siglo Veintiuno, p.86-93.

LEVY, R. A. (2003) Visão topográfica no processo psicanalítico: o irrepresentável. Revista Brasileira de Psicanálise, 37/4, São Paulo, p.1.067-1.077.

RACAMIER, P-C. (1980). Les Schizophrénes. Paris:Payot. (1991) Souffrir et Survivre dans les Paradoxes, Revue Française de Psychanalyse, 55/4, Paris, PUF, p. 893-909.

Maria Emília Sousa Almeida

maealmeida@yahoo.com.br 